\title{
PENERAPAN MODEL PEMBELAJARAN KOOPERATIF TIPE STAD (STUDENT TEAMS ACHIEVEMENT DIVISION) MELALUI METODE TEAM TEACHING PADA MATERI SEGIEMPAT UNTUK MELATIH KECAKAPAN HIDUP SISWA
}

\author{
Lisanul Uswah Sadieda dan Nurul Avivah \\ IAIN Sunan Ampel Surabaya \\ (lisanuluswah@yahoo.com)
}

\begin{abstract}
The graduates of all education level are expected to have all aspect in accordance with national education goals, one of which is life skill. Life skill development in school is influenced by learning process in the classroom, including selection of appropriate learning model. Theoretically, cooperative model STAD (Student Teams Achievement Division) type through team teaching method is suitable to train students' life skill. Because of that, the aim of this research is to know the students' life skill during the learning process of quadrilateral topic using this STAD learning model in the seventh grade of SMP Negeri 4 Surabaya. The research result show that students' life skill are good. It is shown from the average score of rational thinking skill at 2,83 and social skill at 2,63 .
\end{abstract}

Key words : cooperative model STAD type, team teaching, life skill

ABSTRAK : Lulusan pada setiap jenjang pendidikan diharapkan memiliki bekal semua aspek sesuai dengan tujuan pendidikan nasional, salah satunya kecakapan hidup. Pengembangan kecakapan hidup di sekolah dipengaruhi oleh proses pembelajaran di kelas termasuk pemilihan model pembelajaran yang sesuai. Secara teori, model pembelajaran kooperatif tipe STAD (Student Teams Achievement Division) melalui metode Team Teaching sesuai untuk melatih kecakapan hidup siswa. Oleh karena itu, tujuan dari penelitian ini adalah untuk mengetahui bagaimana kecakapan hidup siswa selama proses pembelajaran dengan menggunakan model pembelajaran tersebut di atas pada materi segiempat di kelas VII SMP Negeri 4 Surabaya. Hasil penelitian menunjukkan bahwa kecakapan hidup siswa termasuk dalam kategori baik. Hal ini tampak dari skor rata-rata berpikir rasional sebesar 2, 83 dan kecakapan sosial sebesar 2,63.

Kata kunci : Model kooperatif tipe STAD, team teaching, kecakapan hidup 


\section{PENDAHULUAN}

Undang-Undang Republik Indonesia No. 20 tahun 2003 tentang Sistem Pendidikan Nasional pada pasal 1 ayat (1) menjelaskan bahwa pendidikan adalah usaha sadar dan terencana untuk mewujudkan suasana belajar dan proses pembelajaran agar peserta didik secara aktif mengembangkan potensi dirinya untuk memiliki kekuatan spritual keagamaan, pengendalian diri, kepribadian, kecerdasan, akhlak mulia serta keterampilan yang diperlukan dirinya, masyarakat, bangsa dan negara (Gaza, 2008). Jadi dapat dikatakan bahwa tujuan pendidikan tidak hanya menjadikan peserta didik menguasai materi pembelajaran, tetapi lebih ditekankan untuk membekali peserta didik dengan kecakapan hidup agar nantinya mampu meningkatkan dan mengembangkan dirinya sebagai pribadi dan anggota masyarakat dalam kehidupan nyata.

Kecakapan hidup adalah kecakapan yang dimiliki seseorang untuk berani menghadapi problem dan kehidupan dengan wajar tanpa merasa tertekan, kemudian secara positif dan kreatif mencari serta menemukan solusi untuk mengatasinya. Kecakapan hidup terdiri atas kecakapan hidup yang bersifat generik dan spesifik.

Kecakapan hidup yang bersifat generik meliputi kecakapan personal dan kecakapan sosial. Kecakapan hidup personal meliputi kecakapan mengenal diri dan kecakapan berpikir rasional. Kecakapan berpikir rasional meliputi kecakapan menggali dan menemukan informasi, kecakapan mengolah informasi, kecakapan mengambil keputusan, dan kecakapan memecahkan masalah (Samani, 2002). Sedangkan kecakapan sosial meliputi kecakapan berkomunikasi lisan maupun tulisan serta kecakapan bekerjasama (Pusat Kurikulum, 2006). Kecakapankecakapan hidup tersebut diperlukan oleh siapapun, baik orang yang bekerja, tidak bekerja, yang sedang sekolah maupun yang tidak sekolah.

Kecakapan hidup yang bersifat spesifik meliputi kecakapan akademik dan kecakapan vokasional. Kecakapan hidup tersebut diperlukan pada saat menghadapi masalah di bidang tertentu, misalnya jika pada saat menghadapi 
komputer yang rusak, maka diperlukan kecakapan khusus tentang komputer (Pusat Kurikulum, 2006).

Kecakapan hidup bukan merupakan mata pelajaran yang berdiri sendiri melainkan terintegrasi melalui mata pelajaran. Oleh karena itu, pendidikan kecakapan hidup dapat merupakan bagian dari semua mata pelajaran yang ada (Tim Broad Based Education, 2003). Mata pelajaran yang diberikan dalam proses pendidikan harus dipahami sebagai alat untuk mengembangkan potensi peserta didik agar pada saatnya nanti mampu mengaktualisasikan diri dan siap menghadapi segala permasalahan kehidupan. Oleh karena itu, materi pelajaran harus dikaitkan dengan kehidupan nyata siswa agar memungkinkan mereka belajar menerapkan isi materi pelajaran untuk memecahkan masalah yang dihadapi dalam kehidupan sehari-hari.

Selain itu, menurut Tim Broad Based Education (2002) pendidikan kecakapan hidup mempertimbangkan tingkat perkembangan peserta didik sesuai dengan jenjang pendidikan yang ditempuh. Pada jenjang pendidikan dasar yaitu TK, SD/MI, SMP/Mts dan yang sederajat akan lebih ditekankan pada perkembangan kecakapan hidup yang bersifat generik. Untuk pengembangan kecakapan hidup yang bersifat spesifik sebaiknya diberikan pada tahapan pengenalan dan disesuaikan dengan perkembangan fisik maupun psikologis siswa. Pengembangan kecakapan hidup ini diberikan sebagai pemandu bakat dan minat siswa.

Berdasarkan uraian di atas, maka penekanan kecakapan hidup dalam penelitian ini adalah kecakapan generik karena subjek penelitian ini adalah siswa kelas VII SMP. Kecakapan generik yang diamati dalam penelitian ini yaitu kecakapan berpikir rasional dan kecakapan sosial siswa. Peneliti memilih kedua kecakapan ini karena sesuai jika diintegrasikan dalam pelajaran matematika. Sedangkan materi yang akan digunakan dalam penelitian ini adalah materi segiempat dengan sub materi pokok persegi panjang dan persegi karena materi tersebut erat hubungannya dengan kehidupan nyata siswa sehingga diharapkan 
dapat membantu mereka memecahkan masalah yang dihadapi dalam kehidupan sehari-hari. Misalnya untuk menghitung keliling dan luas halaman rumah yang berbentuk persegi panjang.

Pengembangan kecakapan hidup di sekolah dipengaruhi oleh proses pembelajaran di dalam kelas. Model dan metode yang digunakan dalam kegiatan belajar mengajar sangat mempengaruhi kecakapan hidup siswa. Salah satu alternatif model pembelajaran yang dapat diterapkan adalah model pembelajaran kooperatif tipe STAD (Student Teams Achievement Division). Model pembelajaran kooperatif tipe STAD adalah salah satu model pembelajaran yang berpotensi menjadikan siswa sebagai pusat pembelajaran (Nur dan Wikandari, 2000). Hal ini dikarenakan model pembelajaran kooperatif tipe STAD menghendaki siswa saling bekerja sama, berinteraksi, dan berkomunikasi dalam menyelesaikan tugas, sehingga pembelajaran yang terjadi tidak berpusat pada guru melainkan berpusat pada siswa.

Dalam proses pembelajaran kooperatif tipe STAD secara tidak langsung akan terjadi diskusi antar siswa baik dalam satu kelompok maupun antar kelompok, siswa akan dilatih untuk mengeluarkan pendapat/ide, menghargai pendapat/ide teman, menggali dan menemukan informasi, mengolah informasi, mengambil keputusan, dan memecahkan masalah. Semua itu adalah bagian dari kecakapan hidup rasional dan sosial. Jadi dapat disimpulkan bahwa model pembelajaran kooperatif tipe STAD secara teori sesuai dengan konsep kecakapan hidup.

Pembelajaran kooperatif tipe STAD juga memiliki beberapa kekurangan salah satunya apabila jumlah siswa sangat banyak, maka guru akan kesulitan dalam membimbing atau mengkoordinasikan siswa dalam berdiskusi. Untuk meminimalisasi kekurangan tersebut, maka model pembelajaran kooperatif tipe STAD dipandang lebih tepat jika diterapkan dengan metode Team Teaching. Hal tersebut dimaksudkan agar siswa dapat memperoleh perhatian dan bimbingan dari beberapa guru secara berkelompok. Dalam penelitian ini, peneliti memilih metode 
Team Teaching penuh karena pada proses pelaksanaannya, semua kegiatan pembelajaran mulai dari perencanaan, pelaksanaan, dan evaluasi dilakukan bersama-sama oleh tim guru (Goettz, 2000). Semua anggota tim guru akan mengetahui isi dan alur kegiatan pembelajaran yang akan dilaksanakan, sehingga kekurangan dalam proses belajar mengajar dapat dihindari, dan tujuan pembelajaran akan tercapai secara optimal.

Berdasarkan uraian di atas maka penelitian ini bertujuan untuk mengetahui bagaimana kecakapan hidup siswa selama proses pembelajaran kooperatif tipe STAD melalui metode Team Teaching pada materi segiempat di kelas VII SMP Negeri 4 Surabaya. Hasil penelitian ini diharapkan dapat dijadikan sebagai bahan pertimbangan untuk menerapkan metode pembelajaran yang efektif dan efisien untuk melatih kecakapan hidup siswa khususnya pada materi segiempat di kelas VII.

\section{METODE PENELITIAN}

Penelitian ini termasuk penelitian deskriptif kuantitatif dengan menggunakan desain penelitian "The One Shot Case Study". Populasi dalam penelitian ini adalah seluruh siswa kelas VII SMP Negeri 4 Surabaya tahun ajaran 2009 - 2010 yang terdiri dari tujuh kelas. Sampel dari penelitian adalah kelas VII - A yang terdiri dari 37 siswa dan dipilih menggunakan teknik acak dengan cara undian. Sedangkan untuk sampel mengenai kecakapan hidup siswa, hanya diambil 6 siswa yang terdiri dari masing-masing 2 orang berkemampuan tinggi, sedang dan rendah berdasarkan nilai raport serta pertimbangan guru kelas. Kemudian mereka akan belajar dalam satu kelompok yang nantinya akan diamati oleh peneliti.

Perangkat pembelajaran yang digunakan dalam penelitian ini adalah Rencana Pelaksanaan Pembelajaran (RPP) dan Lembar Kegiatan Siswa yang menggunakan model kooperatif tipe STAD melalui metode Team Teaching untuk 
2 kali pertemuan. Indikator pembelajaran pada pertemuan pertama meliputi: menemukan rumus keliling bangun persegi panjang, menemukan rumus luas bangun persegi panjang, menyelesaikan masalah yang berkaitan dengan keliling persegi panjang dan menyelesaikan masalah yang berkaitan dengan luas persegi panjang. Sedangkan indikator pembelajaran pada pertemuan kedua meliputi: menemukan rumus keliling bangun persegi, menemukan rumus luas bangun persegi, menyelesaikan masalah yang berkaitan dengan keliling persegi dan menyelesaikan masalah yang berkaitan dengan luas persegi. Lembar Kerja Siswa berisi langkah-langkah menemukan rumus keliling dan luas bangun persegi panjang dan persegi serta beberapa soal mengambil keputusan dan memecahkan masalah. Dalam menyusun LKS ini peneliti memperhatikan aspek-aspek yang terdapat pada kecakapan berpikir rasional dan sosial, agar LKS ini dapat dijadikan sarana dalam melatih kecakapan hidup siswa pada materi segiempat.

Perangkat pembelajaran telah dinyatakan valid dan direvisi berdasarkan saran validator sebelum digunakan dalam uji coba lapangan. Validator terdiri dari dua orang dosen program studi Pendidikan Matematika IAIN Sunan Ampel Surabaya dan guru bidang studi Matematika SMP Negeri 4 Surabaya. Validasi yang dilakukan mengenai ketepatan dan kelayakan isi, kesesuaian dengan indikator pembelajaran dan tujuan penelitian, keterlaksanaan urutan kerja siswa serta design fisik. Analisis data hasil validasi perangkat pembelajaran dilakukan dengan mencari rata-rata tiap kategori dan rata-rata tiap aspek dalam lembar validasi, hingga akhirnya didapatkan rata-rata total $(\bar{x})$ penilaian validator terhadap masing-masing perangkat pembelajaran. Untuk menentukan kategori kevalidan suatu perangkat diperoleh dengan mencocokkan rata-rata total $(\bar{x})$ dengan kategori kevalidan perangkat pembelajaran menurut Khabibah (2006), sebagai berikut: 
Tabel 1 : Kriteria pengkategorian kevalidan perangkat pembelajaran

\begin{tabular}{|c|c|}
\hline Interval Skor & Kategori Kevalidan \\
\hline $4 \leq \bar{x} \leq 5$ & Sangat valid \\
\hline $3 \leq \bar{x}<4$ & Valid \\
\hline $2 \leq \bar{x}<3$ & Kurang valid \\
\hline $1 \leq \bar{x}<2$ & Tidak valid \\
\hline
\end{tabular}

Instrumen yang digunakan dalam penelitian ini meliputi: a) Lembar validasi perangkat pembelajaran dan tes. b). Lembar pengamatan kecakapan hidup siswa yang terdiri dari dua kecakapan hidup yang diamati yaitu: i) Kecakapan berfikir rasional siswa yang meliputi kecakapan menggali dan menemukan informasi serta kecakapan mengolah informasi. ii). Kecakapan sosial siswa yang meliputi kemampuan dalam menjawab pertanyaan guru, kemampuan dalam mengeluarkan pendapat/ide dalam kelompok, kemampuan dalam menghargai pendapat/ide dalam kelompok, kemampuan dalam mempresentasikan hasil diskusi kelompok, kemampuan menuliskan hasil diskusi dalam kelompok, dan kemampuan bekerja sama dengan anggota kelompok. c). Lembar tes kecakapan berpikir rasional siswa yang berisi satu soal untuk aspek kecakapan dalam memecahkan masalah dan satu soal untuk aspek kecakapan mengambil keputusan. Soal tes yang disusun berupa soal terbuka (open ended) yang telah divalidasi oleh validator yang sama dengan validator perangkat pembelajaran. Validasi yang dilakukan hanyalah validasi isi mengenai kesesuaian soal dengan tujuan pengambilan tes serta bahasa soal.

Data tentang kecakapan sosial siswa dan kecakapan berpikir rasional untuk aspek kecakapan menggali dan mengolah informasi diperoleh melalui metode observasi pada saat pembelajaran berlangsung. Selama melakukan pengamatan, peneliti dibantu oleh seorang rekan peneliti agar lebih fokus dan teliti dalam melakukan pengamatan. Setiap pengamat mengamati tiga orang siswa yang telah 
ditentukan sebelumnya. Sedangkan untuk memperoleh data tentang kecakapan berpikir rasional untuk aspek kecakapan mengambil keputusan dan memecahkan masalah dilakukan tes pada akhir pertemuan pertama dan akhir pertemuan kedua.

Adapun analisis data yang digunakan dijelaskan sebagai berikut: data tentang kecakapan berpikir rasional dan sosial siswa dianalisis dengan menggunakan kriteria yang disajikan dalam bentuk skor dengan rentang nilai 1 4 dengan kategori ;

$$
\begin{array}{ll}
1=\text { tidak baik } & 3=\text { baik } \\
2=\text { kurang baik } & 4=\text { sangat baik }
\end{array}
$$

Dalam mengukur kecakapan berpikir rasional, subjek diberi skor 1 untuk masing-masing hal berikut: i) hanya diam dan tidak menggali serta mengolah informasi; ii) tidak mengerjakan soal tentang mengambil keputusan dan memecahkan masalah dalam lembar tes atau mengerjakannya sebagian tetapi belum benar. Skor 2 diberikan untuk masing-masing hal berikut: i) menggali dan mengolah informasi dari melihat jawaban teman dan informasi yang diperoleh kurang lengkap; ii) mengerjakan sebagian soal terkait pengambilan keputusan dan pemecahan masalah dalam lembar tes dan benar. Skor 3 diberikan untuk masingmasing hal berikut: i) menggali dan mengolah informasi dari penjelasan guru dan teman serta informasi yang diperoleh cukup lengkap; ii) mengerjakan semua soal terkait pengambilan keputusan dan pemecahan masalah dalam lembar tes dan sebagian benar. Sedangkan skor 4 diberikan untuk masing-masing hal berikut: i) menggali dan mengolah informasi dari berdiskusi dengan guru dan teman, membaca, menghitung serta informasi yang diperoleh lengkap; ii) mengerjakan semua soal terkait pengambilan keputusan dan pemecahan masalah dalam lembar tes dan semua benar.

Dalam mengukur kecakapan sosial, subjek diberi skor 1 untuk masingmasing hal berikut: i) hanya diam dan tidak menjawab pertanyaan yang diajukan oleh guru atau teman; ii) hanya diam dan tidak berani mengungkapkan pendapat; 
iii) tidak menghiraukan pendapat orang lain; iv) tidak berani mempresentasikan hasil diskusi di depan kelas; v) dapat menjawab 2 butir soal dalam LKS dan vi) hanya diam dalam kegiatan kelompok. Skor 2 diberikan untuk masing-masing hal berikut: i) mampu menjawab pertanyaan dari guru atau teman tetapi jawaban belum benar; ii) berani mengungkapkan pendapat/ide tetapi belum benar; iii) kurang menerima dan menghargai pendapat / ide orang lain; iv) berani mempresentasikan hasil diskusi di depan kelas, tetapi jawaban salah; v) dapat menjawab 4 butir soal dalam LKS dan vi) hanya menyalin jawaban hasil diskusi tanpa ikut bekerja sama dalam kelompok. Skor 3 diberikan untuk masing-masing hal berikut: i) mampu menjawab pertanyaan dari guru atau teman dan jawaban benar tetapi dengan bahasa yang kurang baik; ii) berani mengungkapkan pendapat dengan benar, tetapi dengan bahasa yang kurang baik; iii) menerima dan menghargai pendapat / ide orang lain meskipun pendapat yang dikemukakan berbeda; iv) berani mempresentasikan hasil diskusi di depan kelas dan jawaban benar tetapi dengan suara yang pelan; v) dapat menjawab 6 butir soal dalam LKS dan vi) bekerjasama dengan anggota kelompok dan saling membantu dalam mengarjakan LKS tetapi belum dapat menyelesaikan dengan tepat waktu. Sedangkan skor 4 diberikan untuk masing-masing hal berikut: i) mampu menjawab pertanyaan dari guru atau teman dan jawaban benar serta menggunakan bahasa yang baik; ii) berani mengungkapkan pendapat dengan benar, dan dengan bahasa yang baik; iii) menerima dan menghargai pendapat / ide orang lain meskipun pendapat yang dikemukakan salah; iv) berani mempresentasikan hasil diskusi di depan kelas dan jawaban benar dengan suara yang lantang; v) dapat menjawab 8 butir soal dalam LKS dan vi) bekerjasama dengan anggota kelompok dan saling membantu dalam mengarjakan LKS dengan tepat waktu

Dari skor tiap aspek yang diamati, dihitung skor rata-rata dengan menggunakan rumus:

$$
\bar{x}=\frac{\sum x_{i}}{n}
$$


Keterangan:

$\bar{x} \quad=$ rata-rata skor kecakapan berpikir rasional atau sosial siswa

$\sum x_{i}=$ jumlah skor tiap aspek yang diamati

$n \quad$ = banyaknya pertemuan (Permadi, 2004)

Selanjutnya nilai rata-rata tersebut dikonversikan oleh Permadi (2004) dengan kriteria pada tabel berikut ini:

Tabel 2: Kriteria kecakapan berpikir rasional dan sosial

\begin{tabular}{|c|c|c|}
\hline No. & $\begin{array}{c}\text { Skor kecakapan berpikir } \\
\text { rasional atau sosial siswa }\end{array}$ & $\begin{array}{c}\text { Kriteria kecakapan berpikir } \\
\text { rasional atau sosial siswa }\end{array}$ \\
\hline 1. & $1,00 \leq \bar{x}<1,50$ & Tidak baik \\
\hline 2. & $1,50 \leq \bar{x}<2,50$ & Kurang baik \\
\hline 3. & $2,50 \leq \bar{x}<3,50$ & Baik \\
\hline 4. & $3,50 \leq \bar{x} \leq 4,00$ & Sangat baik \\
\hline
\end{tabular}

\section{HASIL PENELITIAN DAN PEMBAHASAN}

Kecakapan berpikir rasional siswa terdiri atas kecakapan menggali dan menemukan informasi, mengolah informasi, mengambil keputusan, dan memecahkan masalah. Dari ujicoba lapangan yang dilakukan sebanyak 2 (dua) kali pertemuan diperoleh hasil kecakapan berpikir rasional siswa yang terangkum dalam tabel berikut: 
Tabel 3 : Kecakapan berpikir rasional siswa

\begin{tabular}{|c|c|c|c|c|c|}
\hline \multirow{2}{*}{ No. } & \multirow{2}{*}{$\begin{array}{c}\text { Aspek kecakapan berpikir } \\
\text { rasional }\end{array}$} & \multicolumn{2}{|c|}{$\begin{array}{c}\text { Skor tiap } \\
\text { aspek }\end{array}$} & \multirow{2}{*}{$\begin{array}{c}\text { Rata-rata } \\
\text { skor tiap } \\
\text { aspek }\end{array}$} & \multirow{2}{*}{$\begin{array}{l}\text { Kategori } \\
\text { penilaian }\end{array}$} \\
\hline & & $\begin{array}{c}\text { Pert } \\
1\end{array}$ & $\begin{array}{c}\text { Pert } \\
2\end{array}$ & & \\
\hline 1. & $\begin{array}{l}\text { Menggali dan menemukan } \\
\text { informasi }\end{array}$ & 2,67 & 2,83 & 2,75 & Baik \\
\hline 2. & Mengolah informasi & 2,83 & 3,17 & 3,00 & Baik \\
\hline 3. & Mengambil keputusan & 2,33 & 2,67 & 2,50 & Baik \\
\hline 4. & Memecahkan masalah & 2,83 & 3,3 & 3,07 & Baik \\
\hline \multicolumn{2}{|c|}{$\begin{array}{c}\text { Rata-rata skor kecakapan berpikir } \\
\text { rasional siswa }\end{array}$} & \multicolumn{3}{|c|}{2,83} & Baik \\
\hline
\end{tabular}

Berdasarkan data pada tabel 3 di atas dapat disimpulkan bahwa kecakapan berpikir rasional siswa dikategorikan baik. Dari tabel 3 di atas juga tampak terjadi peningkatan skor pada tiap aspek kecakapan berpikir rasional antara pertemuan pertama dengan pertemuan kedua. Hal ini menunjukkan bahwa model dan metode yang digunakan dalam kegiatan pembelajaran ini (dalam hal ini model kooperatif tipe STAD dengan metode team teaching ) dapat dijadikan sebagai alternatif yang tepat untuk melatih serta meningkatkan kecakapan berpikir rasional siswa. Aspek yang perlu mendapat perhatian lebih serius adalah kecakapan dalam mengambil keputusan. Hal ini terlihat dari skor yang lebih rendah daripada aspek lain. Salah satu penyebabnya karena mereka tidak terbiasa dengan soal terbuka yang mempunyai alternatif jawaban lebih dari satu seperti soal mengambil keputusan pada tes.

Hasil tentang kecakapan sosial siswa terangkum dalam tabel berikut: 
Tabel 4: Kecakapan sosial siswa

\begin{tabular}{|c|c|c|c|c|c|}
\hline \multirow{2}{*}{ No. } & \multirow{2}{*}{$\begin{array}{c}\text { Aspek kecakapan berpikir } \\
\text { rasional }\end{array}$} & \multicolumn{2}{|c|}{$\begin{array}{l}\text { Skor tiap } \\
\text { aspek }\end{array}$} & \multirow{2}{*}{$\begin{array}{l}\text { Rata-rata } \\
\text { skor tiap } \\
\text { aspek }\end{array}$} & \multirow{2}{*}{$\begin{array}{l}\text { Kategori } \\
\text { penilaian }\end{array}$} \\
\hline & & $\begin{array}{c}\text { Pert } \\
1\end{array}$ & $\begin{array}{c}\text { Pert } \\
2\end{array}$ & & \\
\hline 1. & $\begin{array}{l}\text { Kemampuan dalam menjawab } \\
\text { pertanyaan secara lisan (baik dari } \\
\text { guru atau teman) }\end{array}$ & 2,33 & 2,67 & 2,50 & Baik \\
\hline 2. & $\begin{array}{ll}\text { Kemampuan } & \text { dalam } \\
\text { mengeluarkan pendapat } & / \text { ide } \\
\text { dalam kelompok } & \end{array}$ & 2,33 & 2,67 & 2,50 & Baik \\
\hline 3. & $\begin{array}{l}\text { kemampuan dalam menghargai } \\
\text { pendapat / ide dalam kelompok }\end{array}$ & 2,5 & 2,5 & 2,50 & Baik \\
\hline 4. & $\begin{array}{lr}\text { Kemampuan } & \text { dalam } \\
\text { mempresentasikan } & \text { hasil } \\
\text { kelompok } & \end{array}$ & 2,67 & 2,83 & 2,75 & Baik \\
\hline 5. & $\begin{array}{l}\text { kemampuan } \quad \text { dalam } r \text { menulis } \\
\text { jawaban dalam diskusi kelompok }\end{array}$ & 2,5 & 3,00 & 2,75 & Baik \\
\hline 6. & $\begin{array}{l}\text { kemampuan dalam bekerjasama } \\
\text { dengan anggota kelompok }\end{array}$ & 2,67 & 2,83 & 2,75 & Baik \\
\hline \multicolumn{2}{|r|}{$\begin{array}{c}\text { Rata-rata skor kecakapan sosial } \\
\text { siswa }\end{array}$} & \multicolumn{3}{|c|}{2,63} & Baik \\
\hline
\end{tabular}

Dari tabel 4 di atas tampak terjadi peningkatan skor pada tiap aspek kecakapan sosial antara pertemuan pertama dengan pertemuan kedua kecuali pada aspek kemampuan dalam menghargai pendapat/ide dalam kelompok. Selain aspek tersebut aspek kemampuan dalam menjawab pertanyaan dan mengeluarkan pendapat secara lisan juga masih lemah dibanding aspek lain. Hal ini disebabkan karena siswa cenderung diam dan tidak menjawab pertanyaan dari guru karena mereka takut jawaban mereka dianggap salah. Siswa juga cenderung diam dan tidak menghiraukan apabila ada teman yang menyampaikan pendapat / ide dalam diskusi kelompok terutama siswa yang termasuk dalam kategori berkemampuan 
rendah. Namun, terlepas dari kelemahan yang terjadi model kooperatif tipe STAD dengan metode team teaching dapat dijadikan sebagai alternatif untuk melatih serta meningkatkan kecakapan sosial siswa karena berdasarkan data pada tabel di atas dapat disimpulkan bahwa kecakapan sosial siswa masih dikategorikan baik.

\section{SIMPULAN DAN SARAN}

Berdasarkan hasil analisis data penelitian di atas, maka diperoleh simpulan sebagai berikut: kecakapan hidup siswa yang meliputi kecakapan berpikir rasional dan sosial selama mengikuti pembelajaran dengan menggunakan model kooperatif tipe STAD (Student Teams Achievement Division) melalui metode Team Teaching pada materi segiempat di kategorikan baik dengan rata-rata skor kecakapan berpikir rasional sebesar 2,83 dan rata-rata skor kecakapan sosial sebesar 2,63. Oleh karena itu, model kooperatif tipe STAD (Student Teams Achievement Division) melalui metode Team Teaching dapat digunakan oleh guru sebagai alternatif untuk melatih dan meningkatkan kecakapan hidup siswa khususnya pada materi segiempat.

\section{DAFTAR PUSTAKA}

Gaza, A., Standar Nasional Pendidikan, Asa Mandiri, Jakarta, 2008.

Goettz, K., http://www.ucalgary.ca.egallery, 2000, diakses pada 20 Juni 2010.

Khabibah, S., Pengembangan Perangkat Pembelajaran Matematika dengan Soal Terbuka untuk Meningkatkan Kreatifitas Siswa Sekolah Dasar, Disertasi, Program Pasca Sarjana Universitas Negeri Surabaya,Surabaya, 2006.

Nur, M. dan Wikandari, P.R.,Pengajaran Berpusat Kepada Siswa dan Pendekatan Konstruktivis Dalam Pengajaran, Edisi 4, Pusat Sains dan Matematika Sekolah UNESA, Surabaya, 2000.

Permadi, H., Metode Statistika Praktis, JICA Universitas Negeri Malang, Malang, 2004. 
Pusat Kurikulum, Pengembangan Model Pendidikan Kecakapan Hidup, Balitbang Depdiknas, Jakarta, 2006.

Samani, M., Kecakapan Hidup Melalui Pendekatan Pendidikan Berbasis Luas, Tim BBE Depdiknas, Surabaya, 2002.

Tim Broad Based Education, Kecakapan Hidup Life Skill Melalui Pendekatan pendidikan Berbasis Luas, SIC, Surabaya, 2002.

Tim Broad Based Education, Pola Pelaksanaan Pendidikan Kecakapan Hidup, SIC, Surabaya, 2003. 